\title{
Yield and botanical composition of a mixed grass-legume pasture in response to maintenance fertilization
}

\author{
Carlos Mauricio Soares de Andrade ${ }^{1}$, Judson Ferreira Valentim ${ }^{1}$, João Batista Martiniano \\ Pereira $^{1}$, Aliedson Sampaio Ferreira ${ }^{2}$ \\ 1 Embrapa Acre, CP 321, Rio Branco - AC, CEP: 69908-970. \\ 2 USP/ESALQ.
}

ABSTRACT - This study was carried out on a low-productive Brachiaria brizantha cv. Marandu pasture, mixed with Arachis pintoi cv. Belmonte (forage peanut), established 13 years ago in a Red-Yellow Latosol in Acre State, western Brazilian Amazon. The purpose was to evaluate the response of this pasture to different fertilizer combinations, aiming at identifying the nutritional factors responsible for the fall of pasture carrying capacity and for the reduced vigor of forage peanut. It was used a randomized complete block design, with three replications and 12 combinations of nitrogen, phosphorus, potassium, lime, sulfur, and micronutrients (100 kg/ha of $\mathrm{N}, \mathrm{P}_{2} \mathrm{O}_{5}$ and $\mathrm{K}_{2} \mathrm{O} ; 300 \mathrm{~kg} / \mathrm{ha}$ of dolomitic lime; $30 \mathrm{~kg} / \mathrm{ha}$ of sulfur and FTE BR-10). Fertilizers were broadcast in $5 \times 5$-m plots, and the experimental area was isolated from grazing for 35 days. Pasture response to fertilizations showed that nitrogen was the main limiting nutrient to forage production. The other nutrients, applied singly or in a combined way, without nitrogen source, did not change dry matter accumulation rate. Overall, fertilizations with nitrogen provided dry matter accumulation rate of $115 \mathrm{~kg} / \mathrm{ha} / \mathrm{day}$ in comparison to only $32 \mathrm{~kg} / \mathrm{ha} /$ day when nitrogen was not applied. There was no response from forage peanut to fertilization, so, there are other factors responsible for its reduced vigor of regrowth.

Key Words: Amazonia, Arachis pintoi, Brachiaria brizantha, nitrogen, pasture degradation, phosphorus

\section{Produção e composição botânica de uma pastagem consorciada de gramínea e leguminosa em resposta à adubação de manutenção}

RESUMO - Este estudo foi realizado em uma pastagem pouco produtiva de Brachiaria brizantha cv. Marandu, consorciada com Arachis pintoi cv. Belmonte (amendoim-forrageiro), estabelecida há 13 anos em um Latossolo Vermelho-Amarelo no estado do Acre, Amazônia ocidental brasileira. Objetivou-se avaliar a resposta desta pastagem a diferentes combinações de fertilizantes, visando identificar os fatores nutricionais responsáveis pela queda da capacidade de suporte da pastagem e pelo reduzido vigor do amendoim-forrageiro. Foi utilizado o delineamento em blocos completos ao acaso, com três repetições, com 12 combinações de nitrogênio, fósforo, potássio, calcário, enxofre e micronutrientes (100kg/ha de N, $\mathrm{P}_{2} \mathrm{O}_{5}$ e $\mathrm{K}_{2} \mathrm{O} ; 300 \mathrm{~kg} / \mathrm{ha}$ de calcário dolomítico; $30 \mathrm{~kg} /$ ha de enxofre e FTE BR-10). Os fertilizantes foram aplicados em cobertura, em parcelas de $5 \times 5 \mathrm{~m}$, e a área experimental foi isolada do pastejo durante 35 dias. A resposta do pasto à adubação indicou que o nitrogênio foi o principal nutriente limitante à produção de forragem. Os demais nutrientes, aplicados isoladamente ou de forma combinada, sem uma fonte de nitrogênio, não alteraram a taxa de acúmulo de massa seca. Em média, as adubações com nitrogênio proporcionaram taxa de acúmulo de massa seca de $115 \mathrm{~kg} / \mathrm{ha} / \mathrm{dia}$, em comparação à de apenas $32 \mathrm{~kg} / \mathrm{ha} /$ dia quando não foi aplicado nitrogênio. Não houve resposta do amendoim-forrageiro à adubação, logo há outros fatores responsáveis pelo seu reduzido vigor de rebrota.

Palavras-chave: Amazônia, Arachis pintoi, Brachiaria brizantha, degradação de pastagem, fósforo, nitrogênio

\section{Introduction}

The process of regional development in Brazilian Amazon converted 65 million hectares of native vegetation into agricultural land use until 2004 (INPE, 2005). Approximately $80 \%$ of this area - 52 million hectares - is occupied by cultivated pastures and a cattle population of
64 million heads, representing $29 \%$ of the total pasture area and $33 \%$ of the total Brazilian cattle herd (IBGE, 2005).

Farmers in tropical countries are under increasing pressure to cease expansion of livestock activities in native ecosystems areas, especially in rain forests, and at the same time, they are called to improve land use efficiency in production areas. 
The improvement of soil fertility under pastures is one of the main steps in cattle production system intensification in Brazilian Amazon, which are based on cultivated pastures as the main source of nutrients for grazing animals. Inclusion of productive and persistent forage legumes on these pastures has been one of the strategies used to increase the supply of nitrogen and to intensify cattle production systems in Acre state (Valentim et al., 2008).

Maintenance fertilization in cultivated pastures is still a practice rarely used by cattle farmers in Brazilian Amazon, although studies on this theme have started in the late 1970s. Currently, the available information about maintenance fertilization is relatively scarce and somewhat contradictory. For instance, studies recently carried out in Acre and Roraima states have identified nitrogen as the most important soil nutrient to be replenished to maintain pasture productivity (Andrade et al., 2003, 2004; Andrade \& Valentim, 2004; Andrade \& Braga, 2005), while studies carried out during the 1980s and 1990s, mainly in Rondônia and Pará states, have shown that cultivated pastures respond markedly to phosphorus fertilization, but usually they show little response to nitrogen fertilization (Teixeira \& SimãoNeto, 2000; Costa\&Townsend, 2003; Dias-Filho, 2005).

No soil analysis method can accurately determine the availability of nutrients in natural ecosystems, because usually not all factors that influence the nutrient flows in the ecosystem are considered (Binkley \& Vitousek, 1989). This is also true for cultivated pasture ecosystems, where the availability of nutrients is strongly associated with nutrient cycling in the soil-plant-animal system (Carvalho, 1989; Dubeux et al., 2007). In these cases, only field fertilization trials are able to identify nutrient limitations correctly (Binkley \& Vitousek, 1989).

Pasture of Brachiaria brizantha cv. Marandu and Arachis pintoi cv. Belmonte, established 13 years ago in a dystrophic Red-Yellow Latosol in Acre, Brazilian Amazon, was identified to study the effect of maintenance fertilization in the region, since this pasture was never fertilized and it showed both reduced carrying capacity and low vigor of regrowth to the legume. Therefore, a short-term field fertilization trial was carried out to identify if soil nutrient deficiencies were affecting the productivity of this mixed grass-legume pasture.

\section{Material and Methods}

This study was carried out on a private farm $\left(09^{\circ} 52^{\prime} 35^{\prime \prime} \mathrm{S}\right.$ and $67^{\circ} 25^{\prime} 16^{\prime \prime} \mathrm{W}$ ) in the municipality of Senador Guiomard, Acre, Brazil. Average annual rainfall is $1,900 \mathrm{~mm}$, with a well defined dry season from July to September, average daily temperature is $25^{\circ} \mathrm{C}$ and $87 \%$ is the mean relative humidity. The experimental area was a Brachiaria brizantha cv. Marandu (marandugrass) pasture established in 1991, where Arachis pintoi cv. Belmonte (forage peanut) was introduced in 2000. This pasture had never been fertilized and had low carrying capacity. The soil is classified as a Red-Yellow Latosol $\left(\mathrm{pH} \mathrm{H}_{2} \mathrm{O}\right.$, 5.6; $\mathrm{P}$ and $\mathrm{K}$ (Mehlich-1), 1.1 and $35.2 \mathrm{mg} / \mathrm{dm}^{3} ; \mathrm{Ca}^{2+}$ and $\mathrm{Mg}^{2+}$, 1.18 and $0.49 \mathrm{cmol}_{\mathrm{c}} / \mathrm{dm}^{3} ; \mathrm{H}+\mathrm{Al}^{3+}, 6.55 \mathrm{cmol}_{\mathrm{c}} / \mathrm{dm}^{3} ; \mathrm{BS}$, $1.76 \mathrm{cmol}_{\mathrm{c}} / \mathrm{dm}^{3} ; \mathrm{CEC}$ at pH 7.0, $8.31 \mathrm{cmol}_{\mathrm{c}} / \mathrm{dm}^{3} ; \mathrm{V}, 21.1 \%$; OM, $1.70 \mathrm{dag} / \mathrm{dm}^{3}$; clay, $15.6 \%$; silt, $18.3 \%$; sand, $66.1 \%$ ).

Initial sward condition, in terms of total height and forage mass (Table 1), indicated that this mixed pasture was being correctly managed under continuous stocking. However, despite its good stand, the grass component showed signs of chlorosis. Peanut forage showed only regular vigor of regrowth and its percentage in botanical composition (6.7\%) was lower than the expected four years after it had been planted. The level of weed infestation (mainly sedges) and percentage of ground cover characterized the pasture as "productive", according to criteria of agricultural degradation of pastures established by Dias-Filho (2005).

The experiment was established during the rainy season, in December 2004, with twelve fertilizer combinations arranged in a randomized complete block design, with three replications. Nitrogen, phosphorus and potassium were applied at two different levels ( 0 and $100 \mathrm{~kg} / \mathrm{ha}$ of $\mathrm{N}, \mathrm{P}_{2} \mathrm{O}_{5}$ and $\left.\mathrm{K}_{2} \mathrm{O}\right)$, in the forms of urea ( $45 \%$ $\mathrm{N})$, triple superphosphate $\left(45 \% \mathrm{P}_{2} \mathrm{O}_{5}, 20 \% \mathrm{CaO}, 1.5 \% \mathrm{~S}\right)$ and potassium chloride $\left(58 \% \mathrm{~K}_{2} \mathrm{O}\right)$, setting a $2^{3}$ factorial, plus four additional fertilizer combinations: NPK + lime (300 kg/ha of dolomitic lime), NPK + S (30 kg/ha of sulfur), NPK + micronutrients ( $30 \mathrm{~kg} / \mathrm{ha}$ of fritted trace elements FTE BR-10) and complete - N (P, K, lime, S and micronutrients).

Table 1 - Initial sward condition and botanical composition of the mixed marandugrass and forage peanut pasture

\begin{tabular}{lrcc}
\hline $\begin{array}{l}\text { Pasture } \\
\text { characteristic }\end{array}$ & $\begin{array}{c}\text { Mean } \pm \text { standard } \\
\text { deviation }\end{array}$ & Minimum & Maximum \\
\hline Sward height (cm) & $27.9 \pm 2.3$ & 20.9 & 32.3 \\
Bare ground (\%) & $19.0 \pm 8.2$ & 4.7 & 47.7 \\
$\begin{array}{l}\text { Forage mass } \\
\text { (kg/ha of DM) }\end{array}$ & $2,865 \pm 320$ & 1,963 & 3,455 \\
Marandugrass (\%) & $82.8 \pm 5.9$ & 71.7 & 94.3 \\
Forage peanut (\%) & $6.7 \pm 3.8$ & 1.0 & 16.3 \\
Weeds (\%) & $10.5 \pm 4.3$ & 4.0 & 20.0 \\
Forage peanut & $3.3 \pm 0.2$ & & 3.6 \\
vigor (from 1 to 5) & & 2.8 & \\
\hline 1 = very bad; 2 = bad; 3 = regular; $4=$ good; 5 = excellent. &
\end{tabular}

R. Bras. Zootec., v.39, n.8, p.1633-1640, 2010 
The fertilizers were applied uniformly to $5 \times 5$ m plots and the experimental area was protected from grazing for 35 days, when pasture response to fertilization was evaluated. Sward condition in each plot was characterized in relation to height $(\mathrm{cm})$, ground cover (\%), forage mass (kg/ha), botanical composition (marandugrass, forage peanut and weeds) and legume vigor, immediately before fertilization and after grazing off period. Samplings were performed at three points in each plot, in a systematic way. Sward height was measured with a graduated ruler and ground cover, botanical composition and legume vigor were visually estimated inside a $0.5 \mathrm{~m} \times 0.5$-m area. Initial forage mass was determined by double sampling technique, based on sward height (cm) and ground cover (\%) index ( HCI = height $\times$ ground cover $/ 100$ ) and a calibration equation obtained from 12 samples clipped to a $10 \mathrm{~cm}$ stubble height outside the plots. Final forage mass was calculated by clipping two $1.0 \times 1.0 \mathrm{~m}$ samples to a $10 \mathrm{~cm}$ stubble height, in each plot, which were pooled and weighted. Forage samples of $300 \mathrm{~g}$ were oven-dried at $55^{\circ} \mathrm{C}$, for 72 hours, and weighted. Dry mass (DM) accumulation rate ( $\mathrm{kg} / \mathrm{ha} / \mathrm{day})$ was calculated dividing total forage mass accumulated (kg/ha of DM) by 35 days.

Data obtained 35 days after fertilization for sward height, forage mass, botanical composition and legume vigor were adjusted by analysis of covariance using the respective data obtained before fertilization (covariates) to account for initial variation among plots. In addition, percentage data were submitted to angular transformation, and back transformed after analysis for presentation. Two data sets were submitted to analysis of variance, both in a randomized complete block design. The first data set was analyzed according to a $2^{3}$ factorial scheme, with two levels of $\mathrm{N}, \mathrm{P}$ and $\mathrm{K}$ fertilization. Significant interactions $(\mathrm{P}<0.05)$ were conveniently decomposed by using SLICE command of PROC GLM, available in the SAS computer program (Littell et al., 1991). The second data set, consisting of the four additional fertilizer combinations plus the control and NPK, was submitted to analysis of variance with means grouped by the Scott-Knott test, at the $5 \%$ level of probability.

\section{Results and Discussion}

There was a significant triple interaction $(\mathrm{P}<0.05)$ for DM accumulation rate (Table 2) and for sward height (Table 3), but not for ground cover (Table 4). The decomposition of these interactions showed that nitrogen fertilization increased DM accumulation rate and sward height irrespective of $\mathrm{P}$ or $\mathrm{K}$ fertilization, but the application of $\mathrm{P}$ or $\mathrm{K}$ fertilizers only increased pasture growth (sward height and forage mass) when associated with $\mathrm{N}+\mathrm{K}$ and $\mathrm{N}+\mathrm{P}$ fertilizers, respectively. On average, the application of $100 \mathrm{~kg} / \mathrm{ha}$ of $\mathrm{N}$ more than triplicated pasture DM accumulation rate and doubled sward height 35 days after fertilization, when compared with the absence of $\mathrm{N}$ fertilization. This pasture response to NPK fertilization clearly demonstrated that availability of $\mathrm{P}$ and $\mathrm{K}$ were not limiting pasture growth, unless high levels of $\mathrm{N}$ fertilization were used.

The confirmation that this pasture did not respond significantly to phosphorus fertilization in a soil with only $1.1 \mathrm{mg} / \mathrm{dm}^{3}$ of P (Mehlich-1) suggests that this method of analyzing $\mathrm{P}$ availability in soils under established pastures may have serious drawbacks. The same problem was detected in several studies carried out in established pastures in Brazil (Luz et al., 2000; Andrade et al., 2001; Oliveira et al., 2001; Magalhães et al., 2007), and apparently it is caused by the inherent fails of the traditional P extractors that do not have the ability to extract the labile organic and microbial P fractions in the soil(Thien \& Myers, 1992; Cantarutti et al., 2004; Raij, 2004), both important to plant nutrition in field conditions (Thien \& Myers, 1992; Rao, 2001; Siqueira et al., 2004). According to Macedo (2004), the recommendations of P fertilization to pasture establishment are well calibrated to the Cerrado soils, but these recommendations to pasture maintenance are still problematic.

Percentage of ground cover was affected only by $\mathrm{N}$ fertilization, which permitted complete soil coverage by the sward after a 35-day rest period (Table 4) as a result of the

Table 2 - Dry mass accumulation rates (kg/ha/day) in a mixed marandugrass and forage peanut pasture, after a 35-day rest period (NPK fertilization)

\begin{tabular}{|c|c|c|c|c|c|}
\hline \multicolumn{6}{|c|}{ Effect of nitrogen } \\
\hline & \multicolumn{2}{|c|}{$\mathrm{P} 0$} & \multicolumn{2}{|c|}{$\mathrm{P} 100$} & \\
\hline & K0 & K100 & K0 & K100 & Mean \\
\hline No & 32.3 & 33.2 & 33.5 & 24.3 & 30.8 \\
\hline N100 & 88.7 & 74.1 & 105.3 & 140.0 & 102.0 \\
\hline $\mathrm{P}>\mathrm{F}$ & 0.001 & 0.001 & 0.001 & 0.001 & \\
\hline \multicolumn{6}{|c|}{ Effect of phosphorus } \\
\hline & \multicolumn{2}{|c|}{ K0 } & \multicolumn{2}{|c|}{ K100 } & \\
\hline & No & N100 & N0 & N100 & Mean \\
\hline P 0 & 32.3 & 88.7 & 33.2 & 74.1 & 57.1 \\
\hline P 100 & 33.5 & 105.3 & 24.3 & 140.0 & 75.8 \\
\hline $\mathrm{P}>\mathrm{F}$ & 0.912 & 0.115 & 0.379 & 0.001 & \\
\hline \multicolumn{6}{|c|}{ Effect of potassium } \\
\hline & \multicolumn{2}{|c|}{ No } & \multicolumn{2}{|c|}{ N100 } & \\
\hline & P 0 & $\mathrm{P} 100$ & $\mathrm{P} 0$ & P 100 & Mean \\
\hline K0 & 32.3 & 33.5 & 88.7 & 105.3 & 65.0 \\
\hline K 100 & 33.2 & 24.3 & 74.1 & 140.0 & 67.9 \\
\hline $\mathrm{P}>\mathrm{F}$ & 0.931 & 0.367 & 0.159 & 0.003 & \\
\hline
\end{tabular}


higher pasture growth and, consequently, higher leaf area index and light interception.

Fertilization with sulfur, dolomitic lime or micronutrients in addition to NPK fertilization had no significant $(\mathrm{P}>0.05)$ effect on pasture DM accumulation rate, sward height and ground cover, when compared to NPK fertilization alone (Figure 1). In fact, pasture response in terms of DM accumulation rate and sward condition was not affected by the application of these nutrients in addition to PK fertilization (complete $-\mathrm{N}$ ), when compared to the control. These results confirm that the mixed pasture was not limited by deficiencies of $\mathrm{S}, \mathrm{Ca}, \mathrm{Mg}$ or micronutrients and it contributes to increase the evidence that nitrogen was the main soil nutrient limiting pasture yield.

Two experiments carried out on pastures established 20 years ago with Brachiaria humidicola in Quartzarenic Neosols in Roraima, Western Brazilian Amazon, using the same methodology of the present study, also showed that maintenance nitrogen fertilization is essential to restart the productivity of old grass pastures (Andrade \& Braga, 2005).

The productivity of newly-sown grass pastures generally declines after a few years in the tropics and subtropics when maintenance fertilization is not practiced - a phenomenon commonly referred as pasture degradation in Latin America (Cadisch et al., 1994) or pasture run-down in northern Australia (Myers \& Robbins, 1991). Several studies carried out in Western Brazilian Amazon (Neill et al., 1997; Andrade et al., 2003, 2004; Andrade \& Valentim, 2004;

Table 3 - Sward height (cm) in a mixed marandugrass and forage peanut pasture after a 35-day rest period (NPK fertilization)

\begin{tabular}{|c|c|c|c|c|c|}
\hline \multicolumn{6}{|c|}{ Effect of nitrogen } \\
\hline & \multicolumn{2}{|c|}{ P 0} & \multicolumn{2}{|c|}{$\mathrm{P} 100$} & \multirow[b]{2}{*}{ Mean } \\
\hline & K0 & K100 & K0 & K100 & \\
\hline No & 42.1 & 44.0 & 41.2 & 40.9 & 42.1 \\
\hline N100 & 76.0 & 69.2 & 83.0 & 94.8 & 80.7 \\
\hline $\mathrm{P}>\mathrm{F}$ & 0.001 & 0.001 & 0.001 & 0.001 & \\
\hline \multicolumn{6}{|c|}{ Effect of phosphorus } \\
\hline & \multicolumn{2}{|c|}{ K0 } & \multicolumn{2}{|c|}{ K100 } & \\
\hline & No & N100 & No & N100 & Mean \\
\hline $\mathrm{P} 0$ & 42.1 & 76.0 & 44.0 & 69.2 & 57.8 \\
\hline P 100 & 41.2 & 83.0 & 40.9 & 94.8 & 65.0 \\
\hline $\mathrm{P}>\mathrm{F}$ & 0.809 & 0.067 & 0.398 & 0.001 & \\
\hline \multicolumn{6}{|c|}{ Effect of potassium } \\
\hline & \multicolumn{2}{|c|}{ N0 } & \multicolumn{2}{|c|}{ N100 } & \\
\hline & $\mathrm{P} 0$ & $\mathrm{P} 100$ & $\mathrm{P} 0$ & P 100 & Mean \\
\hline K0 & 42.1 & 41.2 & 76.0 & 83.0 & 60.6 \\
\hline K100 & 44.0 & 40.9 & 69.2 & 94.8 & 62.2 \\
\hline $\mathrm{P}>\mathrm{F}$ & 0.598 & 0.933 & 0.073 & 0.005 & \\
\hline
\end{tabular}

Andrade \& Braga, 2005), central Brazil (Drudi et al., 1995; Oliveira et al., 2001) and Australia (Robbins et al., 1989; Robertson et al., 1993) have demonstrated that a decline in

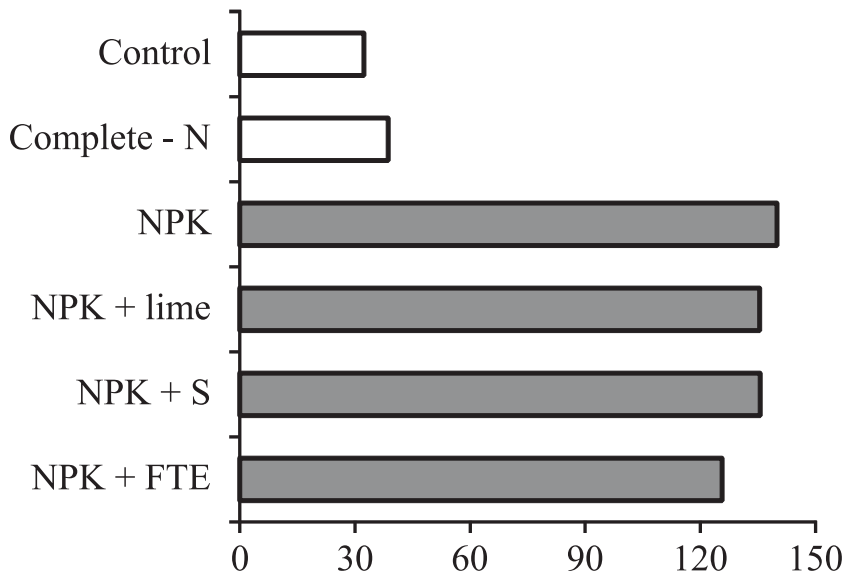

DM accumulation rate ( $\mathrm{kg} / \mathrm{ha} /$ day $)$
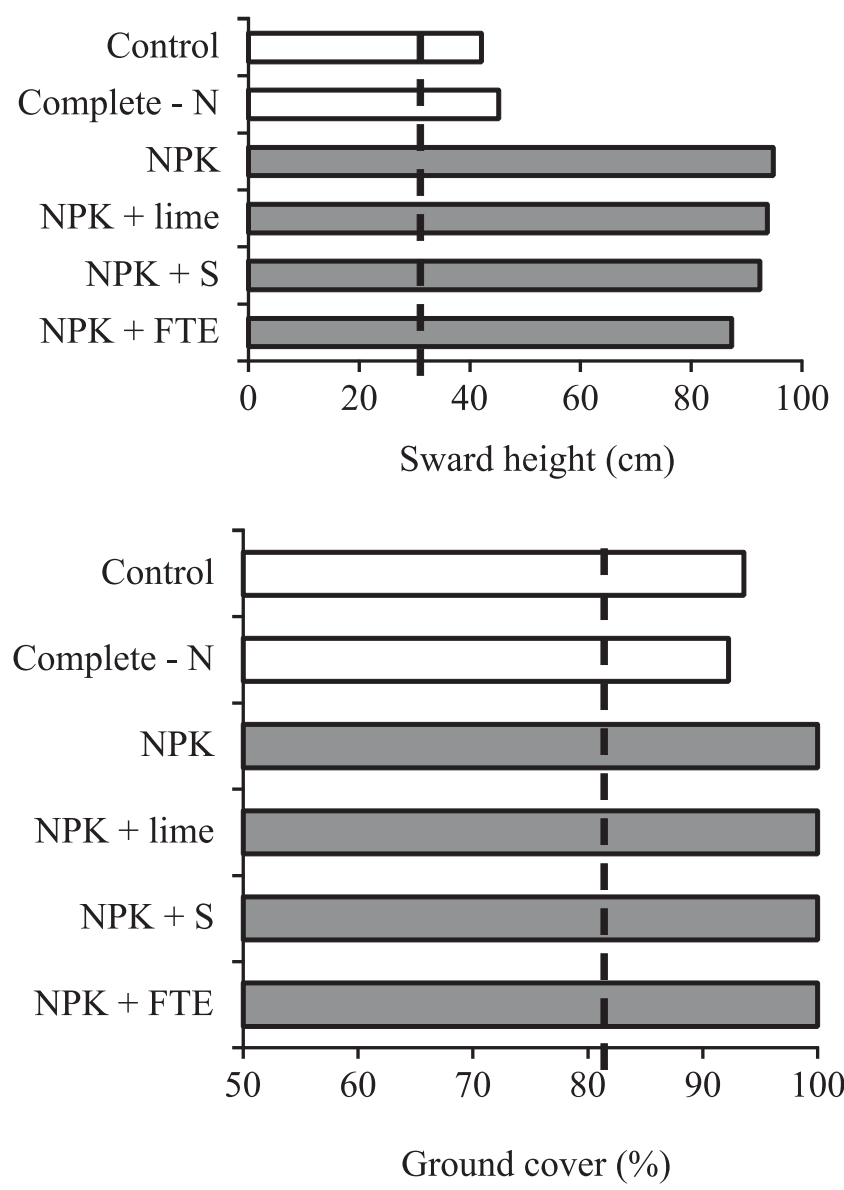

Treatments with the same color bars, in each graphic, are groups by Scott-Knott test, at the $5 \%$ level. Dotted lines show initial sward condition.

Figure 1 - Effect of fertilizer combinations on DM accumulation rate, sward height and ground cover in a mixed pasture, after a 35-day rest period. 
soil nitrogen availability is one of the main causes of this phenomenon. The causes of the decreased soil $\mathrm{N}$ availability have been attributed to an accumulation of low-quality plant litter and root materials in C4 grasslands and, consequently, to an increase in net immobilization by soil microorganisms (Robbins et al., 1989; Robertson et al., 1993; Urquiaga et al., 1998). The annual $\mathrm{N}$ deficit in tropical grass pastures have been estimated in 60 to $100 \mathrm{~kg} / \mathrm{ha}$ (Myers \& Robbins, 1991; Cadisch et al., 1994).

Despite the broad occurrence of soil $\mathrm{N}$ deficiency in non-fertilized aged grass pastures in tropical and subtropical regions, the results of studies carried out in the Brazilian Amazon during the 1980s and 1990s mainly in Rondônia and Pará states, have led to a commonly accepted concept that cultivated pastures in the region respond markedly to phosphorus fertilization, but they usually show little response to nitrogen fertilization (Teixeira \& Simão Neto, 2000; Costa \& Townsend, 2003; Dias-Filho, 2005). The discussion about this controversy is out of the scope of the present paper, but the current level of knowledge about $\mathrm{N}$ cycling and maintenance $\mathrm{N}$ fertilization in tropical grass swards suggests that this concept may be failed. Research on tropical areas since the 1960s clearly demonstrated the highly responsive nature of tropical grasses to $\mathrm{N}$ fertilization (Martha Jr. et al., 2007). In the Peruvian Amazon, the dry mass production of Brachiaria decumbens increased linearly up to doses of $400 \mathrm{~kg} / \mathrm{h}$ a of $\mathrm{N}$ per year (Toledo \& Morales, 1982). In Acre, Panicum maximum cv. Tanzânia also responded linearly to nitrogen fertilization up to doses of $180 \mathrm{~kg} / \mathrm{ha}$ of N per growing cycle (Andrade et al., 2003).

Other evidences that old grass pastures in the Brazilian Amazon were limited by soil nitrogen deficiency have been brought by studies of soil $\mathrm{N}$ transformations in chronosequences of forests and pastures at different ages. For example, Neill et al. (1997) examined soil inorganic N concentrations, net mineralization and nitrification rates in

Table 4 - Percentage of ground cover, marandugrass and forage peanut in a mixed pasture, after a 35-day rest period (NPK fertilization)

\begin{tabular}{|c|c|c|c|}
\hline & $\mathrm{N}$ & $\mathrm{P}_{2} \mathrm{O}_{5}$ & $\mathrm{~K}_{2} \mathrm{O}$ \\
\hline Dose $(\mathrm{kg} / \mathrm{ha})$ & & Ground cover (\%) & \\
\hline 0 & 91.3 & 96.5 & 95.4 \\
\hline 100 & 100.0 & 94.8 & 96.0 \\
\hline $\mathrm{P}>\mathrm{F}$ & 0.001 & 0.180 & 0.557 \\
\hline Dose (kg/ha) & & Marandugrass (\%) & \\
\hline 0 & 77.6 & 84.5 & 84.7 \\
\hline 100 & 89.5 & 82.7 & 82.5 \\
\hline $\mathrm{P}>\mathrm{F}$ & 0.001 & 0.420 & 0.315 \\
\hline Dose (kg/ha) & & Forage peanut (\%) & \\
\hline 0 & 8.9 & 5.7 & 6.6 \\
\hline 100 & 5.0 & 8.3 & 7.3 \\
\hline $\mathrm{P}>\mathrm{F}$ & 0.042 & 0.134 & 0.498 \\
\hline
\end{tabular}

six forests and eleven pastures established 3 years ago or before on ultisols and oxisols that encompassed a wide variety of soil textures and spanned a 700-km geographical range on the state of Rondônia, southwestern Brazilian Amazon. Rates of net $\mathrm{N}$ mineralization and net nitrification were lower in pasture soils than in forest soils, and this was not related to changes in soil total carbon or nitrogen concentrations. According to the authors, the consistent pattern of lower rates of net $\mathrm{N}$ transformations on pasture soils compared with forest soils across a range of soil types, soil textures and pasture ages suggest that changes to soil $\mathrm{N}$ cycling caused by deforestation for pasture may be Basin-wide in extent.

The occurrence of soil $\mathrm{N}$ deficiency in non-fertilized aged grass pastures is probably widespread in the Amazon biome as in other tropical regions, and it represents one of the main causes of the high degree of pasture degradation. This assertion is not based only in the present study. Several studies carried out in the Amazon region using a similar methodology have showed that maintenance nitrogen fertilization is essential to restart the productivity of old grass pastures. These experiments were conducted in pastures established with several grass species (Brachiaria brizantha, B. decumbens, B. humidicola and Panicum maximum) in different soil types in states of Acre (Andrade et al., 2003, 2004; Andrade \& Valentim, 2004) and Roraima (Andrade \& Braga, 2005), and also in other countries of the Amazon region, like Bolivia (Vallejos, 1986) and Venezuela (González \& Newman, 1995; Pietrosemoli et al., 1996; Urbano et al., 2005). The implications of this finding are very important to help farmers, extension agents and policy makers to deal with the great problem of pasture degradation in the region.

Despite the short duration of the fertilization trial, consistent changes in botanical composition were observed in response to NPK fertilization in this study. $\mathrm{N}$ fertilization increased the percentage of marandugrass and decreased the percentage of forage peanut (Table 4), probably as a consequence of the higher growth of the grass. Phosphorus or potassium fertilization had no significant effect $(\mathrm{P}>0.05)$ on the percentages of these pasture components; however, there was a tendency for increase in the percentage of forage peanut under $\mathrm{P}$ fertilization.

There was a significant triple interaction $(\mathrm{P}<0.05)$ for the effect of NPK fertilization on percentage of weeds (Table 5). Its decomposition showed that nitrogen fertilization reduced significantly $(\mathrm{P}<0.05)$ the percentage of weeds, regardless of $\mathrm{P}$ or $\mathrm{K}$ fertilization. This is a clear effect of the enhancement of the grass competition capacity against weeds, promoted by $\mathrm{N}$ fertilization. Potassium 
fertilization increased significantly $(\mathrm{P}<0.05)$ the percentage of weeds only when associated with $P$ fertilization (without $\mathrm{N}$ fertilization). Phosphorus fertilization reduced $(\mathrm{P}<0.05)$ weed percentage only when associated with $\mathrm{N}+\mathrm{K}$ fertilizers.

Several studies show that $\mathrm{N}$ fertilization is detrimental to forage peanut in mixed pastures. In Venezuela, $\mathrm{N}$ fertilization increased kikuyu grass (Pennisetum clandestinum) percentage and decreased forage peanut and weeds percentage after a 280-day experimental period (Urbano et al., 2005). The same was reported in a study with the mixture of coastcross (Cynodon dactylon) and Arachis pintoi cv. Amarillo in Paraná State (Paris et al., 2009).

Fertilization with sulfur, dolomitic lime or micronutrients in addition to NPK fertilization had no significant $(\mathrm{P}>0.05)$ effect on pasture botanical composition when compared to NPK fertilization alone (Figure 2), similarly to that observed for pasture yield and sward condition. However, fertilizer combinations including NPK increased the percentage of marandugrass, decreased the percentage of weeds and had no significant effect on percentage of forage peanut in relation to the control and complete minus $\mathrm{N}$.

The vigor of forage peanut was not altered $(\mathrm{P}>0.05)$ by any fertilizer combination (data not presented). However, the vigor of its plants at the end of the experimental period was substantially higher (mean of 3.8), regardless to fertilization, than at the onset of the experiment (mean of 3.3). One of the hypothesis of this study was that some soil nutrient deficiencies were responsible for the reduced vigor of the legume and, consequently, for its low percentage in

Table 5 - Percentage of weeds in a mixed marandugrass and forage peanut pasture, after a 35-day rest period (NPK fertilization)

\begin{tabular}{|c|c|c|c|c|c|}
\hline \multicolumn{6}{|c|}{ Effect of nitrogen } \\
\hline & \multicolumn{2}{|c|}{$\mathrm{P} 0$} & \multicolumn{2}{|c|}{ P 100} & \\
\hline & K0 & K100 & K0 & K100 & Mean \\
\hline N0 & 14.1 & 12.6 & 10.3 & 15.6 & 13.1 \\
\hline N100 & 5.2 & 6.9 & 5.7 & 3.7 & 5.4 \\
\hline $\mathrm{P}>\mathrm{F}$ & 0.001 & 0.009 & 0.012 & 0.001 & \\
\hline \multicolumn{6}{|c|}{ Effect of phosphorus } \\
\hline & \multicolumn{2}{|c|}{ K0 } & \multicolumn{2}{|c|}{ K100 } & \\
\hline & N0 & N100 & No & N100 & Mean \\
\hline P 0 & 14.1 & 5.2 & 12.6 & 6.9 & 9.7 \\
\hline P 100 & 10.3 & 5.7 & 15.6 & 3.7 & 8.8 \\
\hline $\mathrm{P}>\mathrm{F}$ & 0.101 & 0.726 & 0.174 & 0.041 & \\
\hline \multicolumn{6}{|c|}{ Effect of potassium } \\
\hline & \multicolumn{2}{|c|}{ N0 } & \multicolumn{2}{|c|}{ N100 } & \\
\hline & $\mathrm{P} 0$ & P100 & $\mathrm{P} 0$ & $\mathrm{P} 100$ & Mean \\
\hline K0 & 14.1 & 10.3 & 5.2 & 5.7 & 8.8 \\
\hline K100 & 12.6 & 15.6 & 6.9 & 3.7 & 9.7 \\
\hline$P>F$ & 0.480 & 0.027 & 0.230 & 0.199 & \\
\hline
\end{tabular}

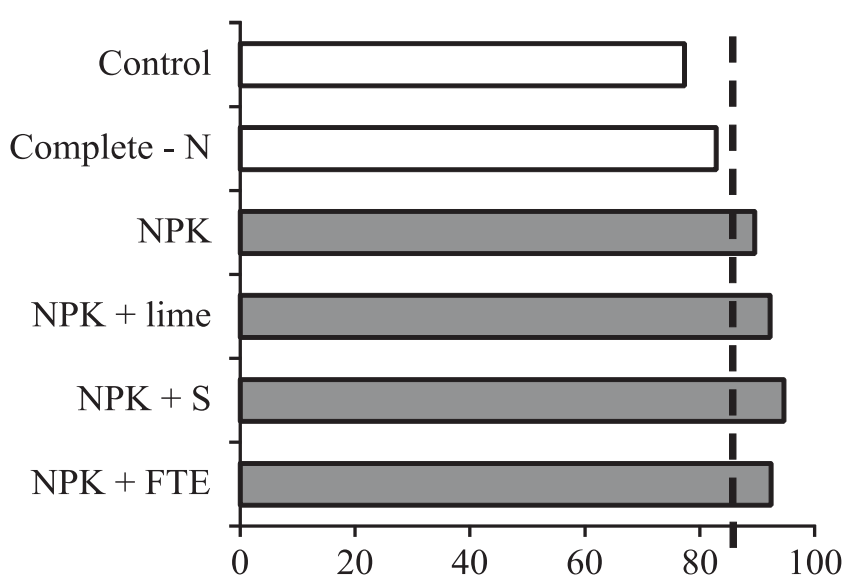

Marandugrass (\%)

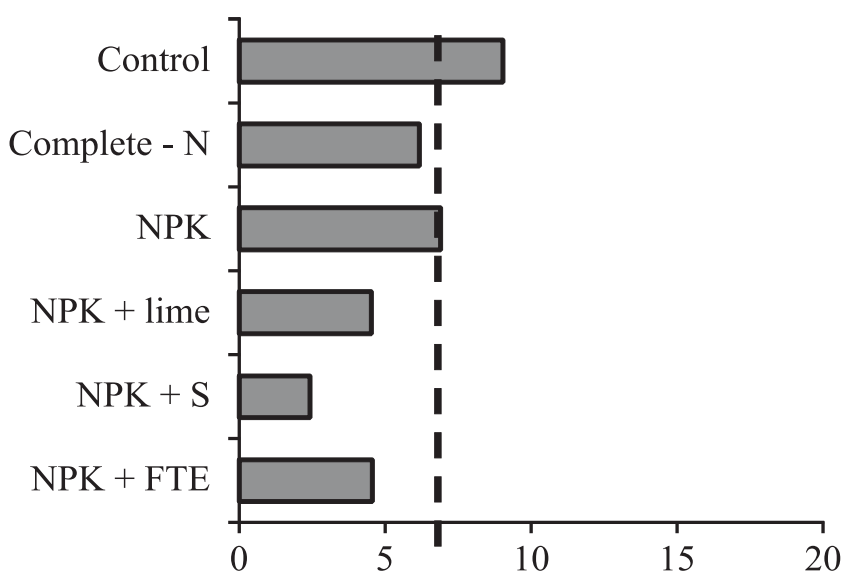

Forage peanut (\%)

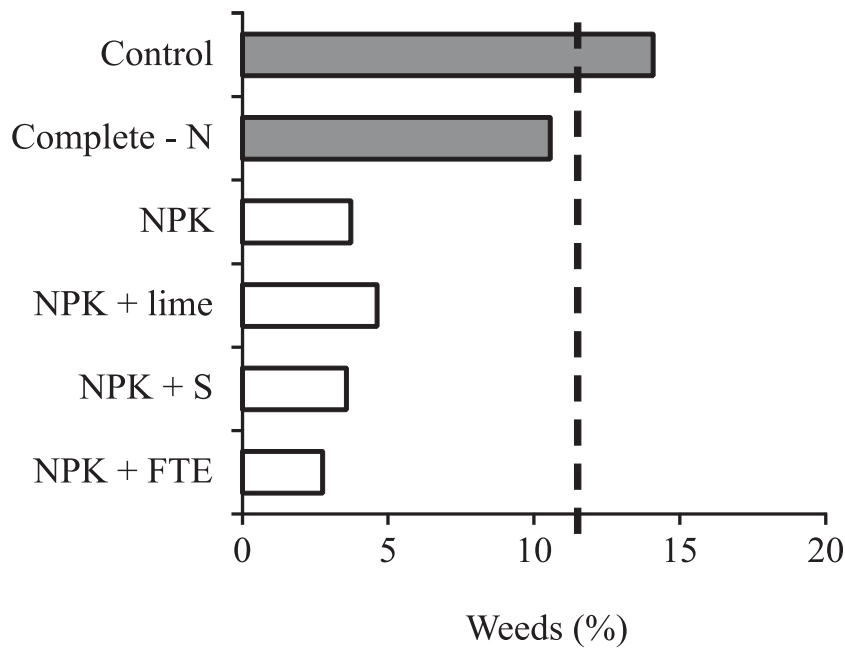

Treatments with the same color bars, in each graphic, are groups by Scott-Knott test, at the $5 \%$ level. Dotted lines show initial sward condition.

Figure 2 - Effect of fertilizer combinations on botanical composition in a mixed marandugrass and forage peanut pasture, after a 35-day rest period. 
a pasture where the grass component had its growth limited by low soil nitrogen availability. However, the lack of response to fertilization and the improvement of its vigor after a 35-day rest period indicate that the hypothesis was incorrect. In fact, considering that forage peanut is a palatable legume, that this pasture had been continuously grazed by milking cows without concentrate supplementation and that the available forage were low in crude protein due to soil $\mathrm{N}$ deficiency and low legume content, it is possible to suppose that the legume had its growth restricted by grazing cattle exercising a high degree of selectivity.

The development of productive and persistent mixed grass-legume pastures has been advocated as an alternative to increase pasture sustainability in the tropics through biological nitrogen fixation and deposition of better-quality litter, which leads to faster nutrient turnover and an increase in nitrogen supply (Thomas, 1992, 1995; Cantarutti et al., 2002). However, low percentages of forage peanut in mixed pastures, as in the present study (6.7\%), are not sufficient to solve the problem of decreasing soil $\mathrm{N}$ availability. According to Thomas (1992, 1995), legumes should range from 20 to $40 \%$ of pasture dry mass to maintain the balance of soil $\mathrm{N}$, depending, among other factors, on rates of pasture utilization. Thus, strategies to assure higher percentages of forage peanut in mixed pastures should be employed to obtain significant levels of $\mathrm{N}$ supply to the pasture ecosystem. Grazing management during and after establishment is clearly one of the tools to manipulate forage peanut percentage in mixed pastures (Ibrahim \& Mannetje, 1998; Andrade et al., 2006).

\section{Conclusions}

The low availability of soil nitrogen is one of the causes of the decline in carrying capacity of Brachiaria brizantha cv. Marandu pastures in Red-Yellow Latosols in Acre. Low percentages of Arachis pintoi cv. Belmonte in mixed grasslegume pastures cannot overcome the low availability of soil nitrogen.

\section{References}

ANDRADE, C.M.S.; BRAGA, R.M. Diagnóstico de nutrientes limitantes no solo de duas pastagens de Brachiaria humidicola em Roraima. In: REUNIÃO ANUAL DA SOCIEDADE BRASILEIRA DE ZOOTECNIA, 42., 2005, Goiânia. Anais... Goiânia: SBZ: UFG, 2005. 6p. (CD-ROM).

ANDRADE, C.M.S.; GALVÃO, R.O.; VALENTIM, J.F. et al. Identificação de nutrientes limitantes da produtividade de pastagens de Brachiaria spp. no Acre. In: REUNIÃO ANUAL DA SOCIEDADE BRASILEIRA DE ZOOTECNIA, 41., 2004, Campo Grande. Anais... Campo Grande: SBZ/Embrapa Gado de Corte, 2004. 6p. (CD-ROM).
ANDRADE, C.M.S.; GARCIA, R.; COUTO, L. et al. Fatores limitantes ao crescimento do capim-tanzânia em um sistema agrossilvipastoril com eucalipto, na região dos Cerrados de Minas Gerais. Revista Brasileira de Zootecnia, v.30, n.4, p.1178-1185, 2001.

ANDRADE, C.M.S.; GARCIA, R.; VALENTIM, J.F. et al. Grazing management strategies for massaigrass-forage peanut pastures. 1. Dynamics of sward condition and botanical composition. Revista Brasileira de Zootecnia, v.35, n.2, p.334-342, 2006.

ANDRADE, C.M.S.; VALENTIM, J.F. Recuperação da capacidade produtiva de uma pastagem de Brachiaria brizantha cv. Marandu com adubação nitrogenada ou fosfatada. In: REUNIÃO ANUAL DA SOCIEDADE BRASILEIRA DE ZOOTECNIA, 41., 2004, Campo Grande. Anais... Campo Grande: SBZ/ Embrapa Gado de Corte, 2004. (CD-ROM).

ANDRADE, C.M.S.; VALENTIM, J.F.; VALLE, L.A.R. Resposta de Panicum maximum cv. Tanzânia a doses crescentes de nitrogênio. In: REUNIÃO ANUAL DA SOCIEDADE BRASILEIRA DE ZOOTECNIA, 40., 2003, Santa Maria. Anais... Santa Maria: SBZ, 2003. 6p. (CD-ROM).

BINKLEY, D.; VITOUSEK, P. Soil nutrient availability. In: PEARCY, R.W.; EHLERINGER, J.; MOONEY, H.A. et al. (Eds.) Plant physiological ecology: field methods and instrumentation. London: Chapman \& Hall, 1989. p.75-96.

CADISCH, G.; SCHUNKE, R.M.; GILLER, K.E. Nitrogen cycling in a pure grass pasture and a grass-legume mixture on a red latosol in Brazil. Tropical Grasslands, v.28, p.43-52, 1994.

CANTARUTTI, R.B.; NOVAIS, R.F.; SANTOS, H.Q. Calagem e adubação fosfatada de pastagens - mitos e realidades. In: SIMPÓSIO SOBRE MANEJO ESTRATÉGICO DA PASTAGEM, 2., 2004, Viçosa, MG. Anais... Viçosa, MG: UFV/DZO, 2004. p.1-23.

CANTARUTTI, R.B.; TARRÉ, R.; MACEDO, R. et al. The effect of grazing intensity and the presence of a forage legume on nitrogen dynamics in Brachiaria pastures in the Atlantic forest region of the south of Bahia, Brazil. Nutrient Cycling in Agroecosystems, v.64, p.257-271, 2002.

CARVALHO, M.M. Manejo da fertilidade do solo para manter a produtividade das pastagens - Curso de pecuária leiteira. Coronel Pacheco: Embrapa-CNPGL, 1989. 34p. (EmbrapaCNPGL. Documentos, 40).

COSTA, N.L.; TOWNSEND, C.R. Alternativas tecnológicas para a redução de queimadas em pastagens da Amazônia Ocidental. Porto Velho: Embrapa Rondônia, 2003. 30p. (Embrapa Rondônia. Documentos, 77).

DIAS-FILHO, M.B. Degradação de pastagens: processos, causas e estratégias de recuperação. Belém: Embrapa Amazônia Oriental, 2005. 2.ed. 173p.

DRUDI, A.; GUIMARÃES, D.M.; MELO, W.R. Recuperação de pastagens degradadas de Brachiaria decumbens nos cerrados do sudoeste goiano - I diagnóstico de deficiências nutricionais. Goiânia: Emgopa, 1995. 9p. (Emgopa. Comunicado Técnico, 50).

DUBEUX, J.C.B., JR.; SOLLENBERGER, L.E.; MATHEWS, B.W. et al. Nutrient cycling in warm-climate grasslands. Crop Science, v.47, p.915-928, 2007.

GONZÁLEZ, R.; NEWMAN, Y. Respuesta del pasto Brachiaria humidicola a la fertilización con nitrógeno, fósforo y potasio en los suelos de "Las Sabanas de la Villa" (Bosque Seco Tropical). Revista de la Facultad de Agronomia, Luz, v.12, n.3, p.331-341, 1995.

IBRAHIM, M.A.; MANNETJE, L.'t. Compatibility, persistence and productivity of grass-legume mixtures in the humid tropics of Costa Rica. 1. Dry matter yield, nitrogen yield and botanical composition. Tropical Grasslands, v.32, n.2, p.96-104, 1998.

INSTITUTO BRASILEIRO DE GEOGRAFIA E ESTATÍSTICA IBGE. Sidra. Disponível em: <http://www.ibge.gov.br>. Acesso em: 20/3/2005.

INSTITUTO NACIONAL DE PESQUISAS ESPACIAIS - INPE. Monitoramento do desmatamento na Amazônia Legal. Disponível em: <http://www.obt.inpe.br>. Acesso em: 20/3/2005. 
LITTELL, R.C.; FREUND, R.J.; SPECTOR, P.C. SAS® system for linear models. Cary: SAS Institute Inc., 1991. 329p.

LUZ, P.H.C.; HERLING, V.R.; LANG, A. et al. Efeito de doses e fontes de fósforo na recuperação de Brachiaria decumbens Stapf. In: REUNIÃO ANUAL DA SOCIEDADE BRASILEIRA DE ZOOTECNIA, 37., 2000, Viçosa, MG. Anais... São Paulo: SBZ, 2000. (CD-ROM).

MACEDO, M.C.M. Adubação fosfatada em pastagens cultivadas com ênfase na Região do Cerrado. In: SIMPÓSIO SOBRE FÓSFORO NA AGRICULTURA BRASILEIRA, 2003, São Pedro, SP. Anais... Piracicaba: POTAFOS, 2004. p.359-400.

MAGALHÃES, A.F.; PIRES, A.J.V.; CARVALHO, G.G.P. et al. Influência do nitrogênio e do fósforo na produção do capimbraquiária. Revista Brasileira de Zootecnia, v.36, n.5, p.1240-1246, 2007.

MARTHA JR., G.B.; VILELA, L.; SOUSA, D.M.G. Adubação nitrogenada. In: MARTHA JR., G.B.; VILELA, L; SOUSA, D.M.G. (Eds). Cerrado: uso eficiente de corretivos e fertilizantes em pastagens. Planaltina: Embrapa Cerrados, 2007. p.117-144.

MYERS, R.J.K.; ROBBINS, G.B. Sustaining productive pastures in the tropics. 5. Maintaining productive sown grass pastures. Tropical Grasslands, v.25, p.104-110, 1991.

NEILL, C.; PICCOLO, M.C.; CERRI, C.C. et al. Net nitrogen mineralization and net nitrification rates in soils following deforestation for pasture across the southwestern Brazilian Amazon Basin landscape. Oecologia, v.110, n.2, p.243-252, 1997.

OLIVEIRA, O.C.; OLIVEIRA; I.P.; FERREIRA, E. et al. Response of degraded pastures in the Brazilian Cerrado to chemical fertilization. Pasturas Tropicales, v.23, n.1, p.14-18, 2001.

PARIS, W.; CECATO, U.; BRANCO, A.F. et al. Produção de novilhas de corte em pastagem de Coastcross-1 consorciada com Arachis pintoi com e sem adubação nitrogenada. Revista Brasileira de Zootecnia, v.38, n.1, p.122-129, 2009.

PIETROSEMOLI, S.; FARIA, L.G.; VILLALOBOS, N. Respuesta del pasto Brachiaria brizantha a la fertilización nitrogenada. Revista de la Facultad de Agronomia, v.13, n.5, p.551-560, 1996.

RobBins, G.B.; BUShelL, J.J.; McKeON, G.M. Nitrogen immobilization in decomposing litter contributes to productivity decline in ageing pastures of green panic (Panicum maximum var. trichoglume). Journal of Agricultural Science, v.113, p.401-406, 1989.

ROBERTSON, F.A.; MYERS, R.J.K.; SAFFIGNA, P.G. Carbon and nitrogen mineralization in cultivated and grassland soils in subtropical Queensland. Australian Journal of Agricultural Research, v.31, p.611-619, 1993.
RAIJ, B. van. Métodos de diagnose de fósforo no solo em uso no Brasil. In: SIMPÓSIO SOBRE FÓSFORO NA AGRICULTURA BRASILEIRA, 2003, São Pedro. Anais... Piracicaba: POTAFOS, 2004. p.563-587.

RAO, I.M. Adapting tropical forages to low-fertility soils. In: INTERNATIONAL GRASSLANDS CONGRESS, 19., 2001, São Pedro. Proceedings... Piracicaba: FEALQ, 2001. p.247-254.

SILVA, D.J. Análise de alimentos: métodos químicos e biológicos. Viçosa, MG: Imprensa Universitária, 1990. 165p.

SIQUEIRA, J.O.; ANDRADE, A.T.; FAQUIN, V. O papel dos microrganismos na disponibilização e aquisição de fósforo pelas plantas. In: SIMPÓSIO SOBRE FÓSFORO NA AGRICULTURA BRASILEIRA, 2003, São Pedro. Anais... Piracicaba: POTAFOS, 2004. p.117-156

TEIXEIRA, L.B.; SIMÃO NETO, M. Renovação e adubação de pastagens. In: COSTA, N.A.; MOURA CARVALHO, L.O.D.; TEIXEIRA, L.B. et al. (Eds.) Pastagens cultivadas na Amazônia. Belém: Embrapa Amazônia Oriental, 2000 p.113-136.

THIEN, S.J.; MYERS, R. Determination of bioavailable phosphorus in soil. Soil Science Society of America Journal, v.56, p.814-818, 1992.

THOMAS, R.J. The role of the legume in the nitrogen cycle of productive and sustainable pastures. Grass and Forage Science, v.47, p.133-142, 1992.

THOMAS, R.J. Role of legumes in providing $\mathrm{N}$ for sustainable tropical pasture systems. Plant and Soil, v.174, n.1-2, p.103-118, 1995.

TOLEDO, J.M.; MORALES, V.A. Estabelecimento e manejo de pastagens melhoradas na Amazônia peruana. In: SÁNCHEZ, P.A.; TERGAS, L.E.; SERRÃO, E.A.S. (Ed.) Produção de pastagens em solos ácidos dos trópicos. Brasília: Editerra Editorial/CIAT/EMBRAPA, 1982. p.199-217.

URBANO, D.; CASTRO, F.; DAVILA, C. Efecto de la presión de pastoreo y fertilización NPK sobre la composición botánica de la asociación kikuyo-maní forrajero en la zona alta del estado Mérida. Zootecnia Tropical, v.23, n.4, p.333-344, 2005.

URQUIAGA, S.; CADISCH, G.; ALVES, B.J.R. et al. Influence of decomposition of roots of tropical forage species on the availability of soil nitrogen. Soil Biology and Biochemistry, v.30, n.14, p.2099-2106, 1998.

VALENTIM, J.F.; ANDRADE, C.M.S.; RESENDE, R.M.S. et al. Leguminosas cultivadas. In: ALBUQUERQUE, A.C.S.; SILVA, A.G. (Org.). Agricultura Tropical: quatro décadas de inovações tecnológicas, institucionais e políticas. Brasília: Embrapa Informação Tecnológica, 2008, v.1. p.1111-1132.

VALLEJOS, A. Niveles de nitrógeno, fósforo y potasio en la producción de forraje de Brachiaria decumbens. Pasturas Tropicales - boletín, v.8, n.1, p.15-17, 1986. 